\title{
Diel movements of juvenile plaice Pleuronectes platessa in relation to predators, competitors, food availability and abiotic factors on a microtidal nursery ground
}

\author{
R. N. Gibson ${ }^{1, *}$, L. Pihl ${ }^{2}$, M. T. Burrows ${ }^{1}$, J. Modin $^{2}$, H. Wennhage ${ }^{2}$, L. A. Nickell ${ }^{1}$ \\ ${ }^{1}$ Centre for Coastal and Marine Sciences, Dunstaffnage Marine Laboratory, PO Box 3, Oban, Argyll PA34 4AD, Scotland, UK \\ ${ }^{2}$ Kristineberg Marine Research Station, S-450 34 Fiskebäckskil, Sweden
}

\begin{abstract}
The distribution and movements of juvenile plaice Pleuronectes platessa and their potential predators and competitors were recorded in a small microtidal $(\sim 20 \mathrm{~cm})$ bay on the west coast of Sweden using underwater television and conventional netting techniques. There was generally close correspondence between the results obtained by the 2 methods. Young plaice moved upshore at dusk and returned to deeper water at dawn. Larger predatory fishes also moved upshore at night but not as far as the plaice; they also entered shallow water later and left for deeper water earlier than the plaice. One interpretation of these nocturnal upshore migrations by plaice, therefore, is that they minimise predation risk. Although stomach fullness was greater at night, the availability of suitable food items for the plaice throughout the bay makes it unlikely that the upshore movements were solely related to feeding. Because there was a strong diel temperature fluctuation in the bay, such movements also ensured that the fish remained in a fairly constant temperature. The main competitor of the plaice for food in July, the shrimp Crangon crangon, showed no such migratory movements and was mostly active during the day. The other dominant large crustacean (Carcinus maenas) was nocturnally active and did not markedly change its depth distribution over the $24 \mathrm{~h}$ period. The observed patterns of movement suggest that the timing of immigration and emigration is mainly triggered by changes in light intensity because only in C. maenas was any relationship found between activity and the phase of the tidal cycle.
\end{abstract}

KEY WORDS: Predation - Feeding - Habitat selection - Migration

\section{INTRODUCTION}

Shallow sandy ecosystems are found throughout the world in a wide range of locations where environmental conditions can vary from extremely exposed to very sheltered and where tidal ranges may be considerable or virtually absent. A great variety of organisms live in such habitats and fishes and crustaceans play important roles in these communities (Brown \& McLachlan 1991). In northern Europe, the numerically dominant macrofauna consists of a few fish species, especially plaice Pleuronectes platessa and gobies of the genus Pomatoschistus, and 2 crustaceans (Crangon crangon and Carcinus maenas) (Macer 1967, Pihl \& Rosenberg

·E-mail: rng@dml.ac.uk
1982, Evans 1983, Gibson et al. 1993). Here, as in many other similar nursery habitats, juvenile stages predominate and their small size renders them vulnerable to a wide variety of predators (Gibson \& Robb 1996). The foraging behaviour of these young animals must therefore take into account not only any tidal, diel and seasonal changes in food availability, but also the risk of predation that may change over these time scales. Furthermore, the high growth rate during the early juvenile stages results in successive changes in their diet, potential predators and competitors. For example, $C$. crangon and $C$. maenas are the main predators on the early benthic stages ( $<30 \mathrm{~mm}$ total length, TL) of plaice in April and May (van der Veer \& Bergman 1987) but the role of these crustaceans changes over the season from predators to potential competitors and in JulyAugust there is a considerable food overlap between 
them (Pihl 1985). It has also been suggested that food may be limited for juvenile plaice, especially during summer and autumn, and reduced growth rate at high plaice densities (Modin \& Pihl 1994) indicates that both intraspecific and interspecific competition could be involved. The biotic characteristics of an optimal environment for juvenile plaice will therefore change during ontogeny. In addition, abiotic factors including temperature and light conditions change over small spatial and temporal scales in both tidal and non-tidal nursery areas. Consequently, patterns of movement are likely to be the result of a complex series of responses to variations in food availability, presence of competitors, predation risk and environmental suitability (e.g. van der Veer \& Bergman 1986, Ansell \& Gibson 1990, Burrows 1994).

The behaviour patterns of individual dominant species on plaice nursery grounds have been studied in some detail (Edwards 1958, Healey 1971, Gibson 1973, 1980, Kuipers 1973, Janssen \& Kuipers 1980, Dare \& Edwards 1981, Hunter \& Naylor 1993, Aagaard et al. 1995) but only rarely have they been considered together (dcl Norte-Campos \& Térinuing 1994, Gibson et al. 1996) or comparisons made between the same species in different habitats (Gibson \& Hesthagen 1981). This paper reports the results of an integrated study of the movements of juvenile plaice in a small, almost tideless sandy bay using a combination of underwater television and conventional sampling techniques. The main objectives of the study were (1) to determine whether the patterns of movement observed could be related to the temporal and spatial distributions of this species' principal predators, prey and competitors and/or to abiotic factors and (2) to compare these movement patterns with those previously observed in a strongly tidal environment (Burrows et al. 1994).

\section{MATERIALS AND METHODS}

Study area. The study was carried out in a shallow bay situated at the mouth of the Gullmarsfjord $\left(58^{\circ} 15^{\prime} \mathrm{N}, 11^{\circ} 28^{\prime} \mathrm{E}\right)$ on the Swedish west coast (Fig. 1). The bay faces north and is moderately exposed to wave action (see Pihl 1986). It has a sandy-silt sediment mixed with shell debris, with an organic content varying spatially between 0.8 and $1.7 \%$. The investigation was carried out from 2 to 12 July 1995, when daylength was approximately $18 \mathrm{~h}$. The sampling area extended from the shore line to a water depth of $1.3 \mathrm{~m}$ (mean water level) $140 \mathrm{~m}$ off shore, including approximately 2 ha. At the outer border of the sampling area is a dense eelgrass Zostera marina meadow beyond which water depth increases rapidly down to about $15 \mathrm{~m}$. Small ( 1 to $10 \mathrm{~m}^{2}$ ) patches of blue mussels

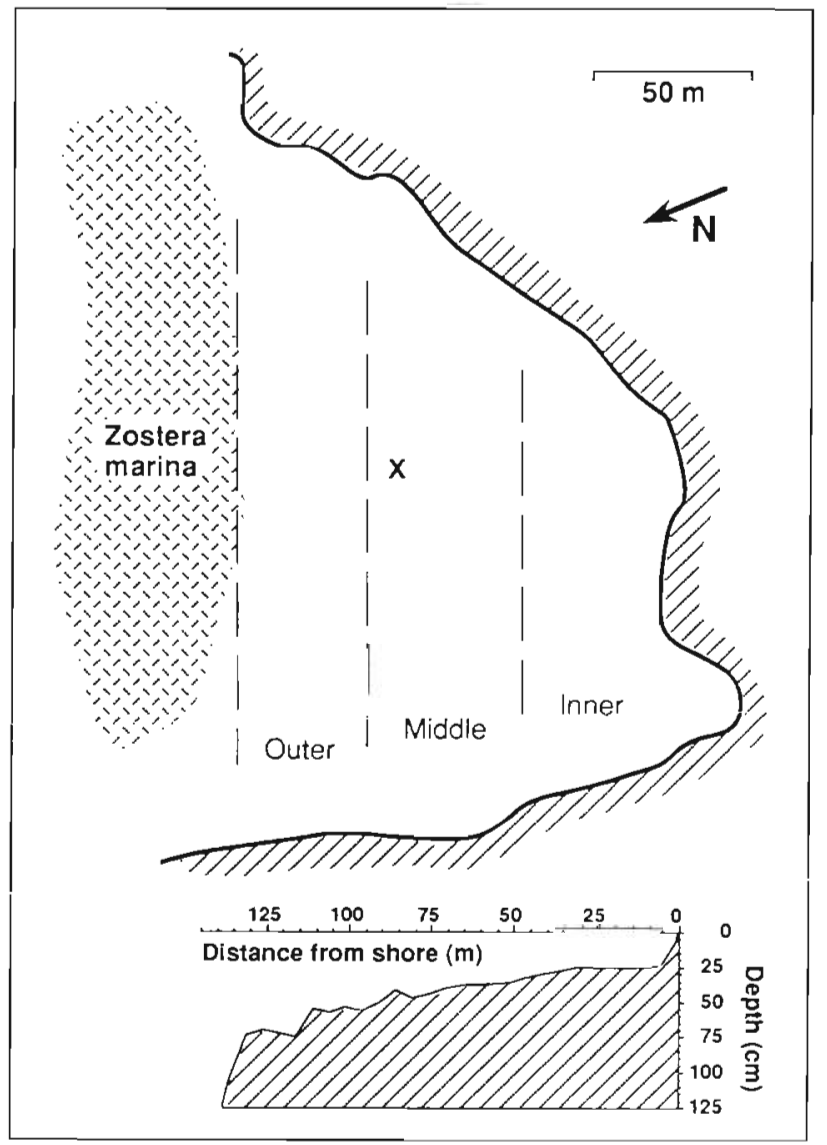

Fig. 1. The study site, Bökevik in the Gullmarsfjord (Swedish west coast). The division into inner (10 to $35 \mathrm{~cm}$ depth), middle $(35$ to $60 \mathrm{~cm})$ and outer strata $(60$ to $130 \mathrm{~cm})$ is indicated. The camera was initially placed at $\mathbf{X}$ but after $7 \mathrm{~d}$ was moved $11 \mathrm{~m}$ downshore. The depth profile of the bay is shown in the lower section of the diagram

Mytilus edulis and eelgrass are present in the centre and outer part of the bay. Tidal amplitude is low (around $20 \mathrm{~cm}$ ) in the study area (Fig. 2) but high pressure fronts can occasionally drain the inner parts of the bay. Mean daily water temperature at $0.5 \mathrm{~m}$ depth normally ranges between 4 and $14^{\circ} \mathrm{C}$ during spring and autumn and between 14 and $20^{\circ} \mathrm{C}$ during summer in such areas (Pihl \& Rosenberg 1982). During winter, ice can cover the bay for 2 to $10 \mathrm{wk}$. During the summer, salinity normally fluctuates from 14 to $24 \%$.

Sampling methods. To investigate spatial and temporal variation in abundance of juvenile 0 -group plaice in relation to abiotic factors, food (benthic infauna), potential competitors (Crangon crangon, Carcinus maenas) and predators (larger migratory fishes), the bay was divided into inner, middle and outer strata for sampling purposes (Fig. 1). Depth at mean water level ranged from 10 to 35,35 to 60 and 60 to $130 \mathrm{~cm}$ in the 3 strata respectively. 
Movements of larger fishes and epibenthic crustaceans were continuously recorded for 2 consecutive periods of 7 and 3 d by means of an underwater television (UWTV) camera situated approximately in the centre of the bay at the level of the middle sampling stratum. The camera was supported above the bottom and facing directly downwards by a metal frame to which were also attached 2 infra-red lights that allowed recording during darkness. The camera was positioned at the centre of an X-shaped arrangement of $1 \mathrm{~m}$ high and $5 \mathrm{~m}$ long fine-mesh nets. The nets, which were weighted at the bottom to keep them in contact with the sediment and supported by floats at the water surface, guided motile species beneath the camera. The camera and lights were connected by underwater cables to a power supply and timelapse video tape-recorder situated in a building on the shore. Full details of the methods and equipment are given by Burrows et al. (1994). Following a marked decrease in water level in the bay on 9 July (Fig. 2), it became necessary to move the camera laterally and to a deeper position approximately $11 \mathrm{~m}$ further downshore for the rest of the recording period.

The resulting video tapes were played back at normal speed and when a fish or crab entered the field of view it was identified as far as possible and the species, time and direction of entry and exit recorded using a computerised event recorder. Most animals moved rapidly through the field of view in one direction but in some species, particularly Carcinus maenas and pipefish, it was clear that the same individual was being recorded more than once. Some individuals of $C$. maenas took up temporary residence at the base of the camera frame and many pipefish appeared to drift to and fro in the water currents. In such cases, only the first appearance of an identifiable individual was counted. Shrimps were too numerous to use this procedure and so similar data were recorded only for the first 5 min of each hour for the first $128 \mathrm{~h}$ of the study. Gobies were greatly attracted to the disturbance of the sediment caused by the installation of the UWTV camera and data for the first 2 days of recording was not used for this species. Measurements of the apparent length of each plaice, gadoid fish and shrimp observed were taken directly from the screen and converted to actual total length to the nearest $0.5 \mathrm{~cm}$ using a predetermined correction factor. Crabs were frequently observed and so the carapace widths to the nearest $0.5 \mathrm{~cm}$ of only the first 30 crabs observed after midnight and midday respectively were measured. For the crustaceans and benthic fishes, the estimations of length will be reasonably accurate because the measurements were calibrated with reference to a scale placed on the sea bed beneath the camera. The lengths of organisms swimming off the bottom, and hence nearer the camera, will therefore have been overestimated.

Abundances and length frequency distributions of 0 group plaice, Crangon crangon and Carcinus maenas were estimated in the bay by taking 5 random samples on 4-5 July in each stratum during both day and night. Sampling was carried out with a $1 \mathrm{~m}$ wide push-net ( $6 \mathrm{~mm}$ mesh size) covering a bottom area of $25 \mathrm{~m}^{2}$. Larger fishes ( $>10 \mathrm{~cm} \mathrm{TL}$ ), expected to migrate into the bay at night, were sampled with a beach seine $1.5 \mathrm{~m}$ high, $38 \mathrm{~m}$ long and with a mesh size of $15 \mathrm{~mm}$ ). Three random hauls, each covering approximately $1000 \mathrm{~m}^{2}$, were taken in the inner and the outer strata on July 6 and 10 during both day and night. Fishes and epibenthic crustaceans from push-net and beach-seine samples were preserved in $70 \%$ ethanol. In the laboratory all individuals in the catches were counted and measured to the nearest $\mathrm{mm}$ (push net samples) or $\mathrm{cm}$ (beach seine samples). The diet was analysed for all 0-group plaice in the push net samples and for all larger fish in the beach seine catches. Few 0-group plaice were caught by push net at night in the outer stratum and samples for diet analysis were augmented with fish from beach-seine catches. Stomach and intestine contents were identified to the lowest possible taxonomic level. Stomach fullness of 0-group plaice was assessed using a scale of 0 to $3(0=$ stomach empty, $1=$ food present in small amounts, 2 = stomach half full, $3=$ stomach full).

Benthic infauna was quantitatively assessed by taking 10 random samples within each stratum on one

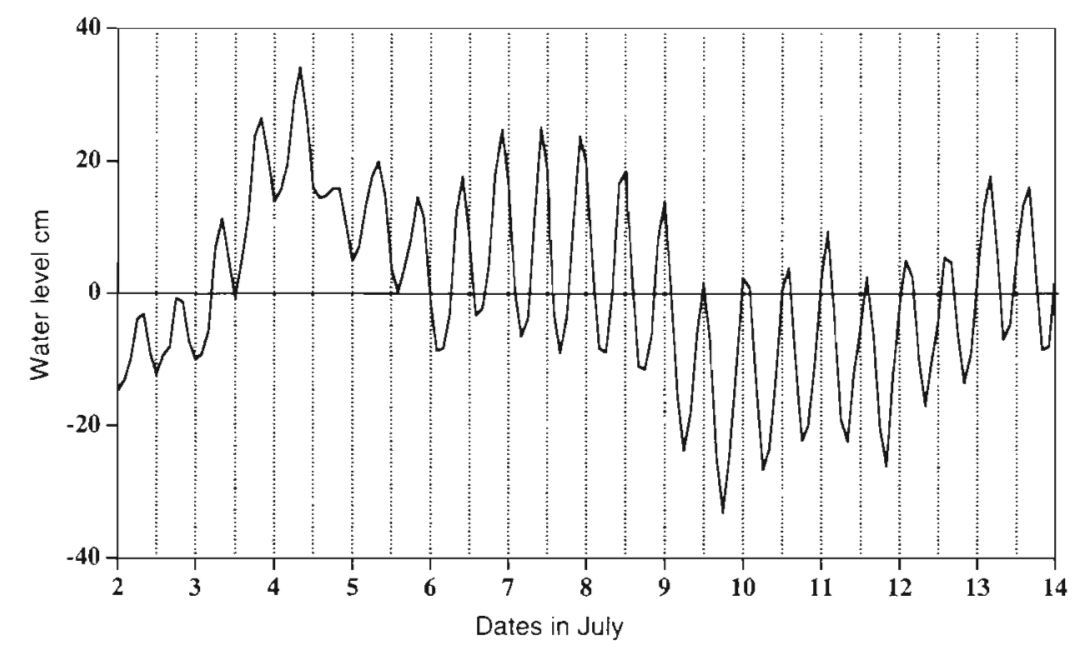

Fig. 2. Variation in water level in Bökevik Bay during the study period 
occasion. Core samples were taken with a plastic cylinder (bottom area $0.05 \mathrm{~m}^{2}$ ) pushed to a depth of $10 \mathrm{~cm}$ into the sediment. The sediment was subsequently washed through a $0.5 \mathrm{~mm}$ sieve and preserved in $4 \%$ formalin. Infauna were identified to the nearest taxonomic group under a stereo microscope and the abundance of each species or faunal group estimated.

Near the mouth of the bay, water level and surface water (1 $\mathrm{m}$ depth) temperature and salinity were continuously (every min) recorded automatically during the investigation. Water temperature was also automatically recorded with continuous recorders just above the bottom sediment in the inner stratum $(30 \mathrm{~cm})$ and the outer stratum $(1 \mathrm{~m})$ over 8 diel cycles during the second half of the study. One meter failed to register, and recordings of water temperature were repeated at the same sites $1 \mathrm{wk}$ after termination of the investigation. Weather conditions during this time were similar to those during the second half of the study and the later temperature measurements are considered representative for the study period. In addition, water temperature was measured at every $10 \mathrm{~m}$ along 4 transects from the shore to the outer border of the study area, $140 \mathrm{~m}$ from the shore, on 8 July during both day and night.

Statistical analysis of data. Two-way ANOVA techniques (Zar 1995) were applied to assess the effects of sample location (inner, middle and outer strata) and time of the day (day and night) on the mean density of plaice, Crangon crangon and Carcinus maenas. Deviations from normality in each data series were assessed by a Cochran test and logarithmic transformations used when necessary. Each length distribution for the 3 areas and the 2 time periods were assumed to be represented by their median lengths. These median lengths were ranked and analysed for plaice, C. crangon and C. maenas with a 2-way Kruskal-Wallis test (Zar 1995). Differences in plaice stomach fullness between day and night were tested in a chi-square analysis of a $2 \times 4$ contingency table.

The results of the video tape analyses were plotted as frequencies of occurrence per unit time to allow any patterns of activity of the commonest species to be detected. These data were summarised by plotting mean frequency per unit time for a $24 \mathrm{~h}$ period from $12: 00 \mathrm{~h}$ to the following $12: 00 \mathrm{~h}$. To determine whether there was any relationship between the patterns of activity observed and variations in water level in the bay, hourly estimates of tidal elevation were obtained from tide gauge data by sinusoidal interpolation between successive heights of high and low water. Because all possible states of the tidal cycle occurred for each hour of the day, it was possible to detect effects of both the diel and the tidal cycles on activity patterns by subjecting the $\log _{10}(1+x)$ hourly frequen- cies to a simple ANOVA in relation to the time of day and the time since the last high water respectively. Trends in activity in relation to the phase of the tidal cycle were also identified by multiple regression of log-transformed frequencies on the cosine and sine components of the angular phase in the cycle (starting at high water). A significant regression coefficient for the cosine component indicates a difference between high water and low water frequencies, while a significant sine component shows a difference between ebb and flood periods. Only 0-group plaice, Carcinus maenas and sand gobies were sufficiently common and recorded for a long enough period to justify such analyses.

Patterns in the direction of movement were analysed by calculating an index of direction, defined as the number of individuals moving upshore per unit time divided by the sum of those moving both up and downshore in the same time period, and plotting the variation in the mean values of this index over a $24 \mathrm{~h}$ period. This index was only calculated for hours in which more than 5 individuals were recorded. The length distributions of plaice, crabs, gadoids and shrimps seen passing beneath the camera during the day and the night were compared using the Kruskal-Wallis test for differences between medians (SAS Institute Inc. 1990).

\section{RESULTS}

\section{Temporal patterns of dominant epibenthic species}

At least 11 species of fishes were observed swimming beneath the UWTV camera, some of which could not be fully identified. The most common were, in descending order of frequency, pipefishes Siphonostoma typhle, 0- and 1-group plaice, gadoids (Gadus morhua juveniles), sand goby Pomatoschistus minutus, bull rout Myoxocephalus scorpius, viviparous blenny Zoarces viviparus and eel Anguilla anguilla. The dominance of these fish species in the bay was confirmed by the push net and beach seine catches. The commonest crustaceans were Crangon crangon and Carcinus maenas. The only other abundant organisms seen were Aurelia aurita and Nassarius reticulata. The temporal patterns of appearance of these dominant species fall into 4 categories: (1) nocturnal species seen only or mostly at night (gadoids, C. maenas, $M$. scorpius, $A$. anguilla and $Z$. viviparus; Figs. 3a, c \& 4a, c, d); (2) diurnal species seen only or mostly during the day (Crangon crangon, pipefish; Figs. 3d \& 4b); (3) crepuscular species seen mostly at dawn and dusk (Pleuronectes platessa; Fig. $3 \mathrm{~b}$ ); and (4) species with no obvious pattern in their appearance $(P$. minutus; Fig. 3e). Moving the camera to the new position on 


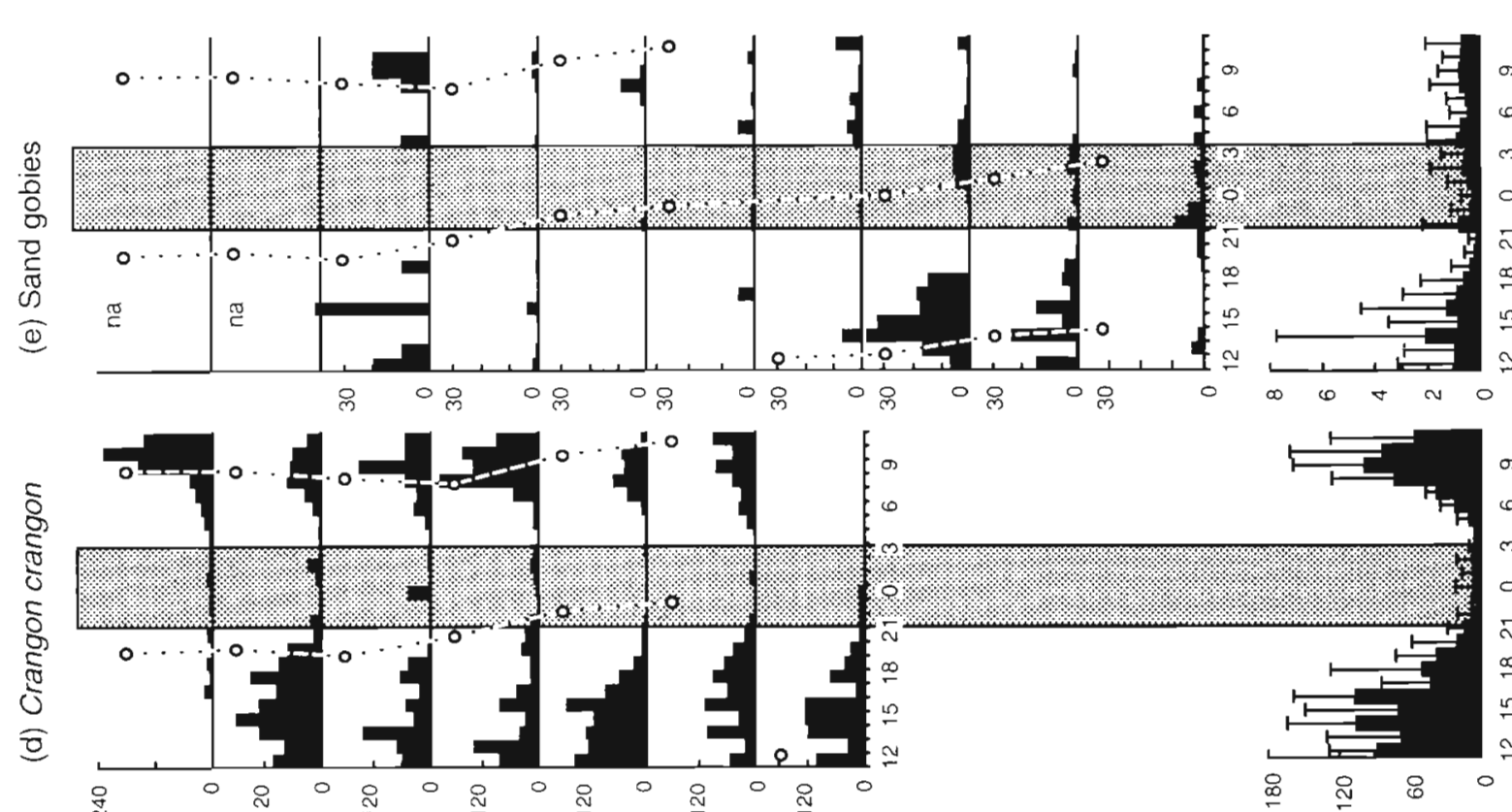

용형 중

is

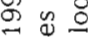

春旦

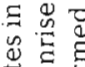

苋

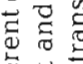

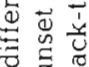

跑

$? 3$

\%

I $\stackrel{x}{\mathscr{\theta}}$

氜吉

壳

3 的家

苗量

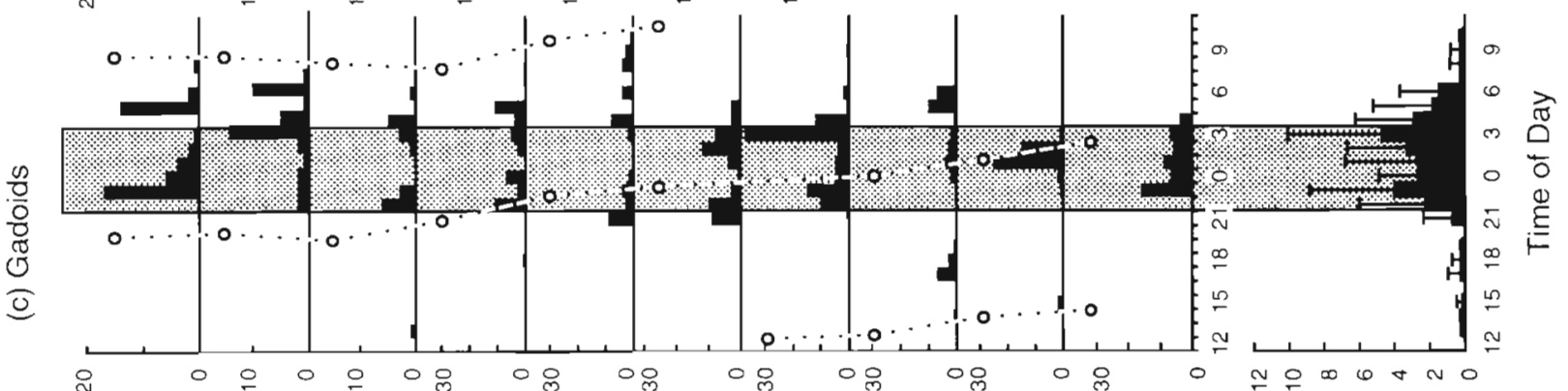

部尔

¿

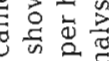

웡 尔

$\overbrace{0}^{0}$ 足

¿

동도

38 둥

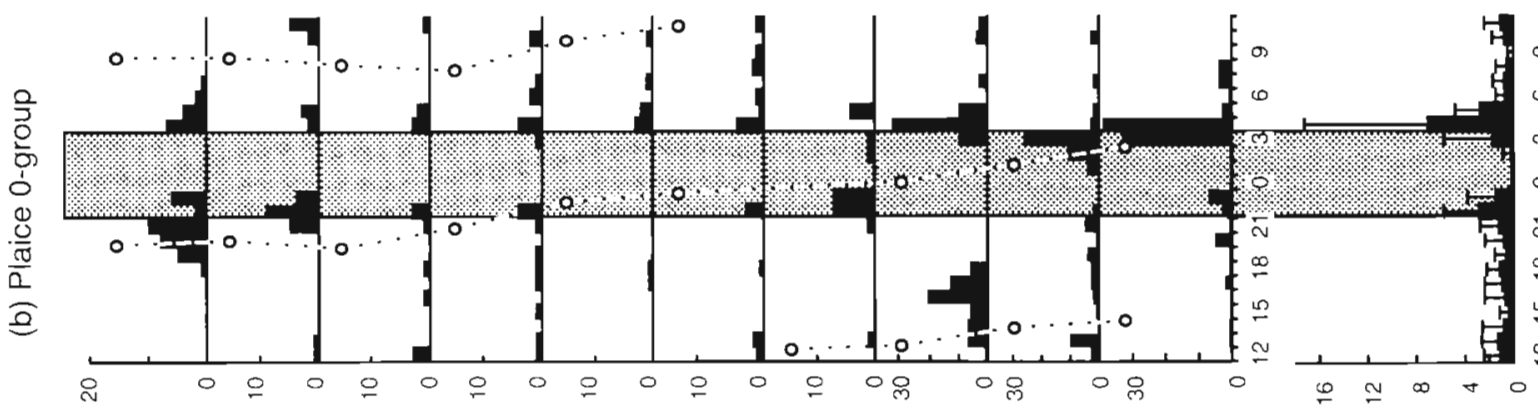

ข

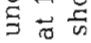

导 苍

믕

$\Xi 93$

究

壳究苍

票焉

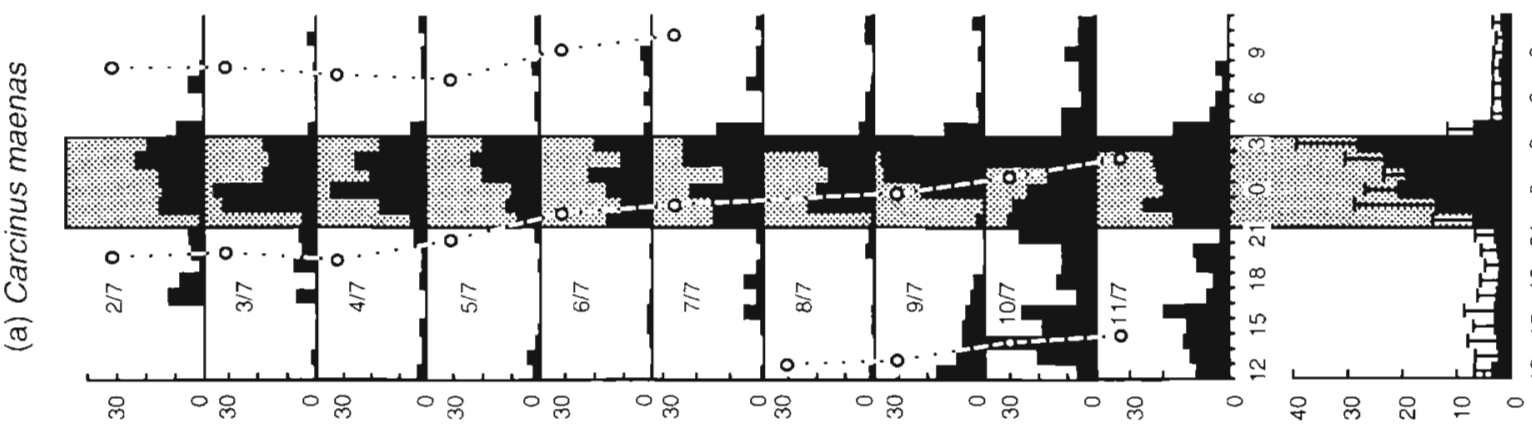

ınou dad ıəqunN

ınoy dad ou ueaw

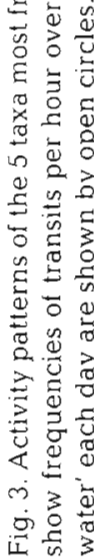




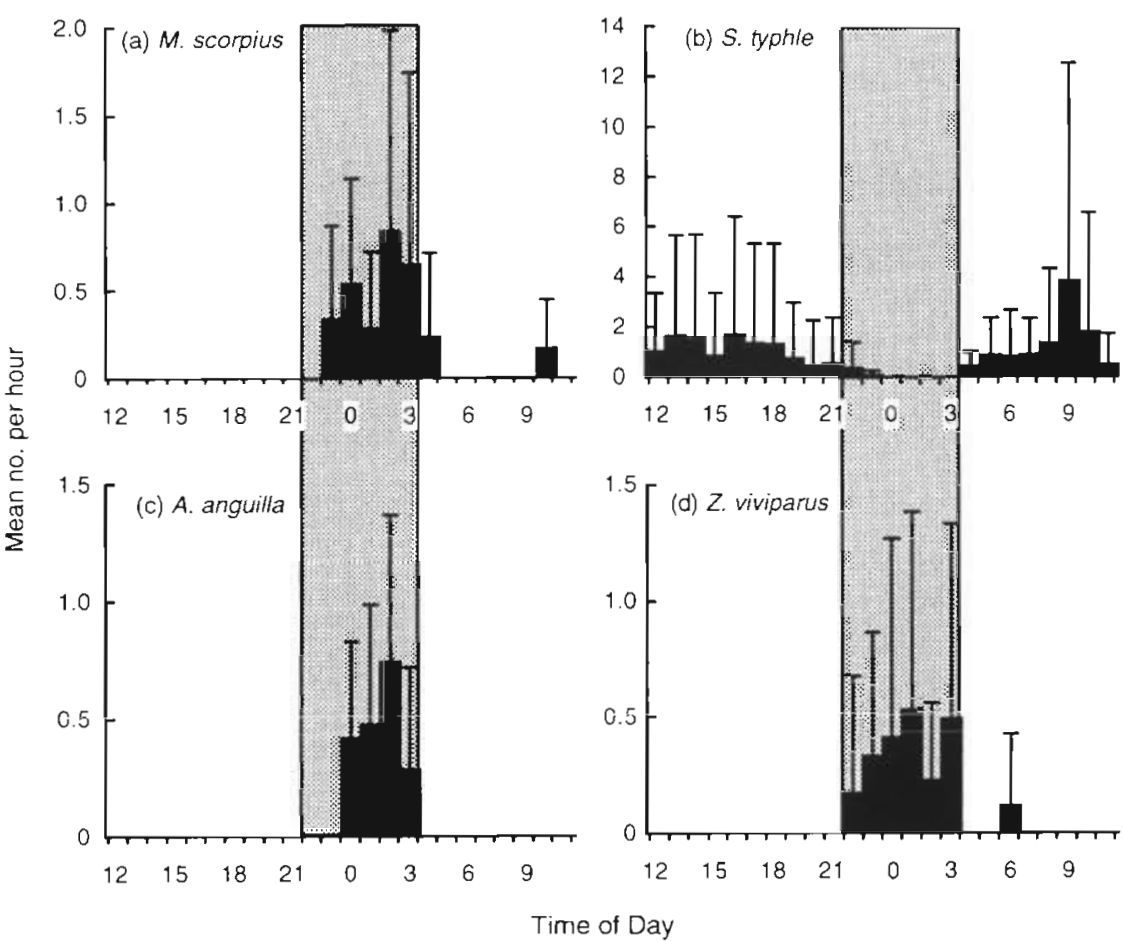

Fig. 4. Average patterns of activity of (a) Myoxocephalus scorpius, (b) Siphonostoma typhle, (c) Anguilla anguilla and (d) Zoarces viviparus per hour of the day. Means and $95 \%$ confidence limits shown were back-calculated from means and confidence limits of $\log _{10}(1+x)$ transformed numbers seen under the camera por hour
9 July resulted in the sighting of large numbers of Pomatoschistus sp. and an increase in the numbers of $C$. maenas and $P$. platessa seen during the day (Fig. 3). The activity patterns of 0 -group plaice and $C$. maenas showed highly significant differences among the means for each hour of the day (Table 1, Hour of day effect), while numbers of all 3 species varied significantly among dates. Analysis of frequencies with respect to time in hours after high water showed no significant differences among hourly means for any of the species (Table 1, Hour after high water effect).

Table 1. Probabilities of $F$-values and associated degrees of freedom of effects tested in 4 separate ANOVAs on $\log _{10}(1+x)$ transformed frequencies of observations per hour from the underwater camera

\begin{tabular}{|c|c|c|c|c|}
\hline Source & df & $\begin{array}{c}\text { 0-group } \\
\text { plaice } \\
\text { p }\end{array}$ & $\begin{array}{c}\text { Carcinus } \\
\text { maenas } \\
\text { p }\end{array}$ & $\begin{array}{c}\text { Sand } \\
\text { goby } \\
\text { p }\end{array}$ \\
\hline Hour of day & 23 & 0.0001 & 0.0001 & 0.7858 \\
\hline Date & 10 & 0.0007 & 0.0001 & 0.0001 \\
\hline Hour after high water & 13 & 0.5327 & 0.4869 & 0.4922 \\
\hline Date & 10 & 0.0146 & 0.0001 & 0.0001 \\
\hline Cosine (tide time): HW vs LW & 1 & 0.1252 & 0.0773 & 0.0334 \\
\hline Sine (tide timc): Ebb vs Flood & 1 & 0.1538 & 0.0076 & 0.2590 \\
\hline Date & 10 & 0.0115 & 0.0001 & 0.0001 \\
\hline Water level per hour $(\mathrm{cm})$ & 1 & 0.2796 & 0.0007 & 0.1350 \\
\hline Date & 10 & 0.0190 & 0.0001 & 0.0001 \\
\hline
\end{tabular}

However, when frequencies were analysed using circular regression in relation to the phase of the tidal cycle (Table 1, Cosine and Sine effects), a highly significant tidal component in the C. maenas activity pattern became apparent. Crabs appeared most frequently $2 \mathrm{~h}$ after the time of high water and were $50 \%$ less frequent at the time of least activity $3 \mathrm{~h}$ after low water. Crab activity also increased with elevated water levels (Table 1, Water level effect), but such an effect also includes atmospheric influences on the depth of water in the bay. The influence of this longer-term variation in water level was investigated by correlation of daily means of frequencies with daily means of water levels. 0-group plaice and sand gobies were seen much more frequently on days of depressed water levels (average $-10 \mathrm{~cm})(0$-group plaice: Kendall's tau $=-0.56, \mathrm{n}=12, \mathrm{p}<0.05$; sand gobies: Kendall's tau $=-0.53, \mathrm{n}=12, \mathrm{p}<$ $0.05)$. This is, however, likely to be an artefact of the disturbance caused by the setting up and relocation of the television camera on 2 and 9 July respectively. The correlation between daily average C. maenas activity and water level was extremely small, suggesting that the effect of increased water level on activity in this species is purely due to the short term variation associated with the tides. 
Analysis of the direction of movement of these species (Fig. 5) showed that the majority of the fish species undertook a diel migration into and out of shallow water. In all cases except Anguilla anguilla, Pomatoschistus minutus, Myoxocephalus scorpius and Zoarces viviparus this migration led to a bimodal peak of appearance beneath the camera which was clearest in Pleuronectes platessa (Figs. $3 \& 4$ ). This species started to move upshore at about 21:00 h and downshore at about 03:00 to 05:00 h (Fig. 5d). P. minutus showed a similar pattern (Fig. 5g). Nocturnal species appeared later in the evening when it was fully dark and left earlier in the morning. The gadoids' pattern of change in directionality (Fig. 5b), characterised by a weak upward movement in the evening followed by a strong downshore movement at dawn, suggests a gradual dispersion into shallow water during darkness followed by a rapid emigration at dawn. Of the rarer fishes, sig-
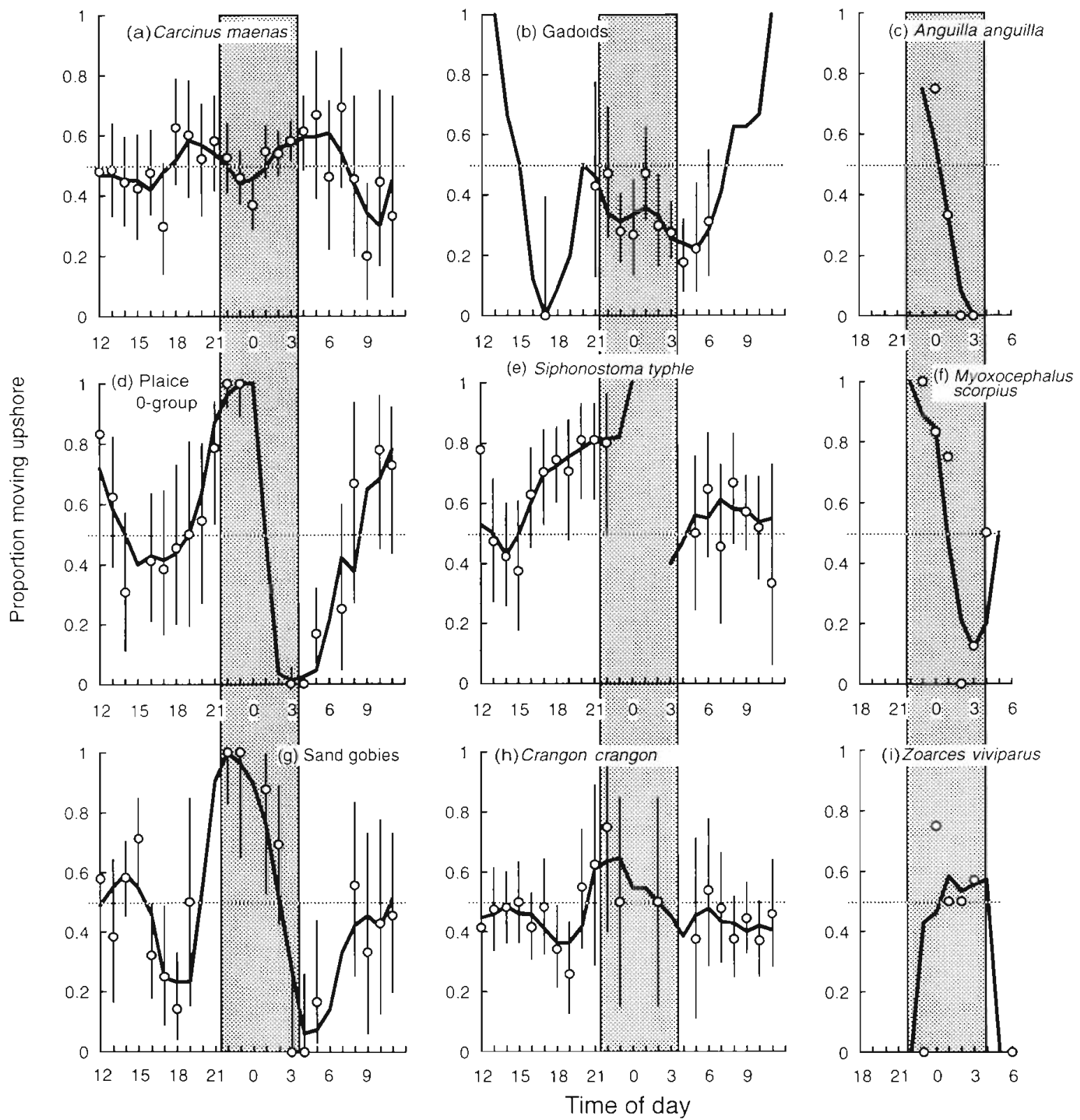

Fig. 5. Diel changes in direction of movement of 9 taxa under the underwater television camera. Open circles show the proportions moving upshore out of total numbers moving up or down the shore. $95 \%$ confidence intervals were calculated based on the number of animals observed (Zar 1995). Only those data based on 5 or more observations are shown, except in (c), (f) and (i) (see text for statistical comparisons). The heavy line connects $3 \mathrm{~h}$ moving averages of the proportions 

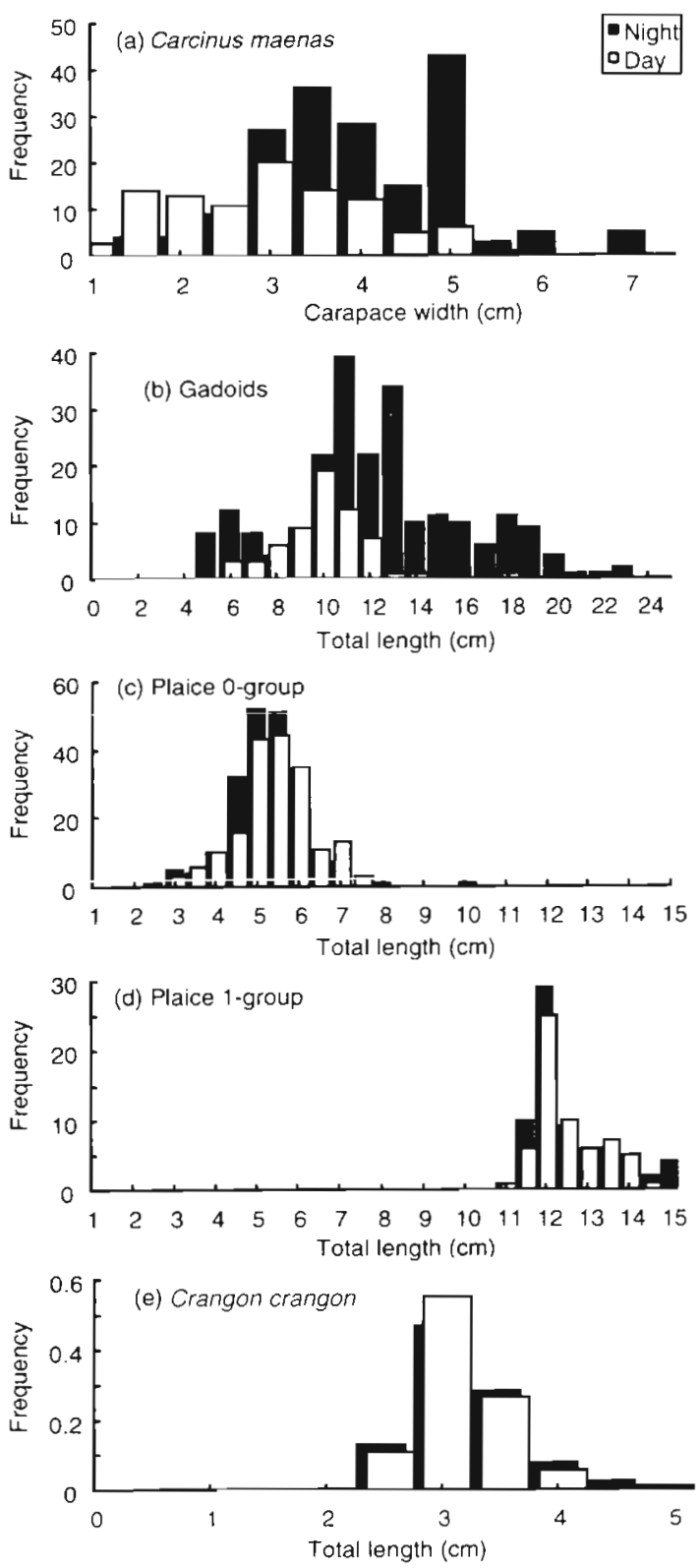

Fig. 6. Size-frequency distributions of commoner species seen beneath the camera by day $(05: 00$ to $21: 59 \mathrm{~h})$ and night (22:00 to $04: 59 \mathrm{~h}$ ). For clarity of presentation, frequencies in (e) are expressed as proportions because there was approximately an order of magnitude difference in the numbers seen during the day and night

nificantly more eels (Fig. 5c, $\mathrm{p}=0.019$ ) and $M$. scorpius (Fig. 5f, p < 0.001) moved upshore before 01:00 h and downshore after 01:00 h (Fisher's exact 1-tail test). In contrast, no significant differences could be detected for $Z$. viviparus (Fig. $5 \mathrm{i}, \mathrm{p}=0.727$ ). Directionality of movement in the 2 crustacean species was variable and no marked upshore or downshore migrations were evident (Fig. 5a, h).
Crabs and gadoid fishes seen at night (22:00 to 04:59 h) were significantly larger $(\mathrm{p}<0.0001)$ than those seen during the day (05:00 to 21:59 h) (Fig. 6) but no such differences were detectable in shrimps $(p=$ 0.337 ) and large $(>10 \mathrm{~cm})$ plaice $(p=0.472$. Fig. 6$)$. Although the mean length of plaice $<10 \mathrm{~cm}$ seen at night was significantly smaller $(p=0.043)$ than of those seen during the day, the difference amounted to only $2 \mathrm{~mm}$ and was within the limits of the detection procedure.

\section{Abundance and length distribution of plaice, shrimp and crabs}

The results from the push-net sampling showed that during the day, abundances of plaice were similar in the inner and middle strata but significantly higher in

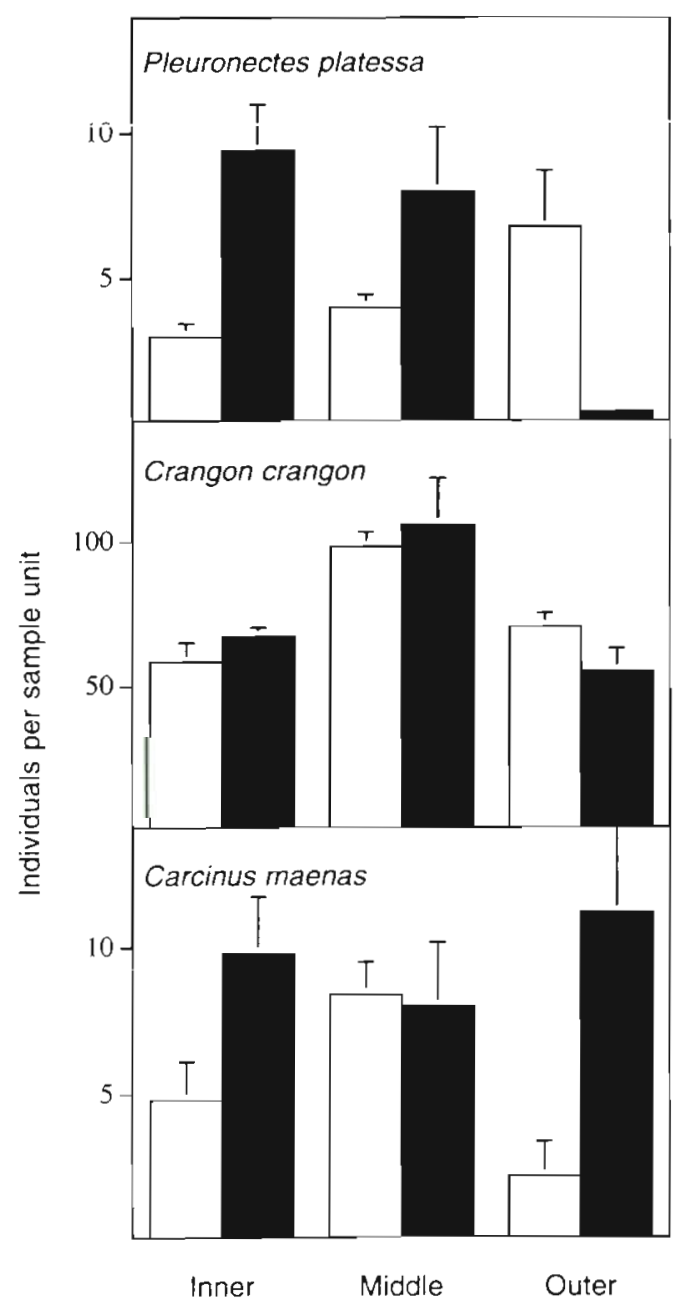

Fig. 7. Variation in the mean number (+SD) of individuals of Pleuronectes platessa, Crangon crangon and Carcinus maenas caught with the push net at each of the 3 strata during the day (white columns) and the night (black columns) 
Table 2. Two-way ANOVA for effect of factors Area (inner, middle, outer strata) and Time (day, night) on mean density. $\mathrm{n}=5, \mathrm{df}=$ degrees of freedom, $\mathrm{SS}=$ sum of squares. $\mathrm{p}<0.05$, $\cdots p<0.01, \cdots p<0.001$; ns: not significant

\begin{tabular}{|lcccc|}
\hline \multicolumn{2}{r}{$\begin{array}{r}\text { Species: } \\
\text { Data transformation: }\end{array}$} & $\begin{array}{c}\text { P. platessa } \\
\ln (x+1)\end{array}$ & $\begin{array}{c}\text { C. crangon } \\
\ln (x+1)\end{array}$ & $\begin{array}{c}\text { C. maenas } \\
\text { None }\end{array}$ \\
Factor & $\mathrm{df}$ & $\mathrm{SS}$ & $\mathrm{SS}$ & $\mathrm{SS}$ \\
\hline Time & 1 & $0.08 \mathrm{~ns}$ & $0.01 \mathrm{~ns}$ & $154.13 \cdots$ \\
Area & 2 & $3.25 \cdots$ & $1.55 \cdots$ & $11.40 \mathrm{~ns}$ \\
Time $\times$ Area & 2 & $9.77 \cdots$ & $0.25 \mathrm{~ns}$ & $112.27 \mathrm{~ns}$ \\
Residual & 24 & 3.69 & 1.42 & 424.40 \\
\hline
\end{tabular}

the outer stratum (Fig. 7, Table 2). During the night, abundances were doubled in the inner and middle strata and were reduced by $>90 \%$ in the outer stratum compared with daytime sampling. Total length of 0 group plaice ranged from 22 to $68 \mathrm{~mm}$ and there was no significant difference in the estimated median lengths of the sampled fish between strata or time of the day (Fig. 8, Table 3). However, the significant interaction between strata and time is due to the upshore movements of plaice at night. The abundance of Crangon crangon was similar in the inner and outer strata, but significantly higher in the middle stratum (Fig. 7, Table 2). No difference in shrimp abundance between day and night was detected in any strata. Shrimp length frequency distribution was similar in all strata (Fig. 8) and median lengths did not differ significantly between time of the day (Table 3) but smaller shrimps dominated in the middle stratum. Carcinus maenas were more abundant during the night in the inner and outer strata but there was no difference in the middle stratum (Fig. 7). The size of crabs did not differ significantly between strata during the day but the median length was significantly greater at night, mainly due to the presence of larger crabs in the samples from the inner and the outer strata (Fig. 8, Table 3).

\section{Predatory fish species and their stomach contents}

No fishes $>10 \mathrm{~cm}$ total length were caught during the day with the beach seine. At night 10 species were caught (Table 4). In total. 75 individuals were collected, of which two thirds were taken in the outer stratum
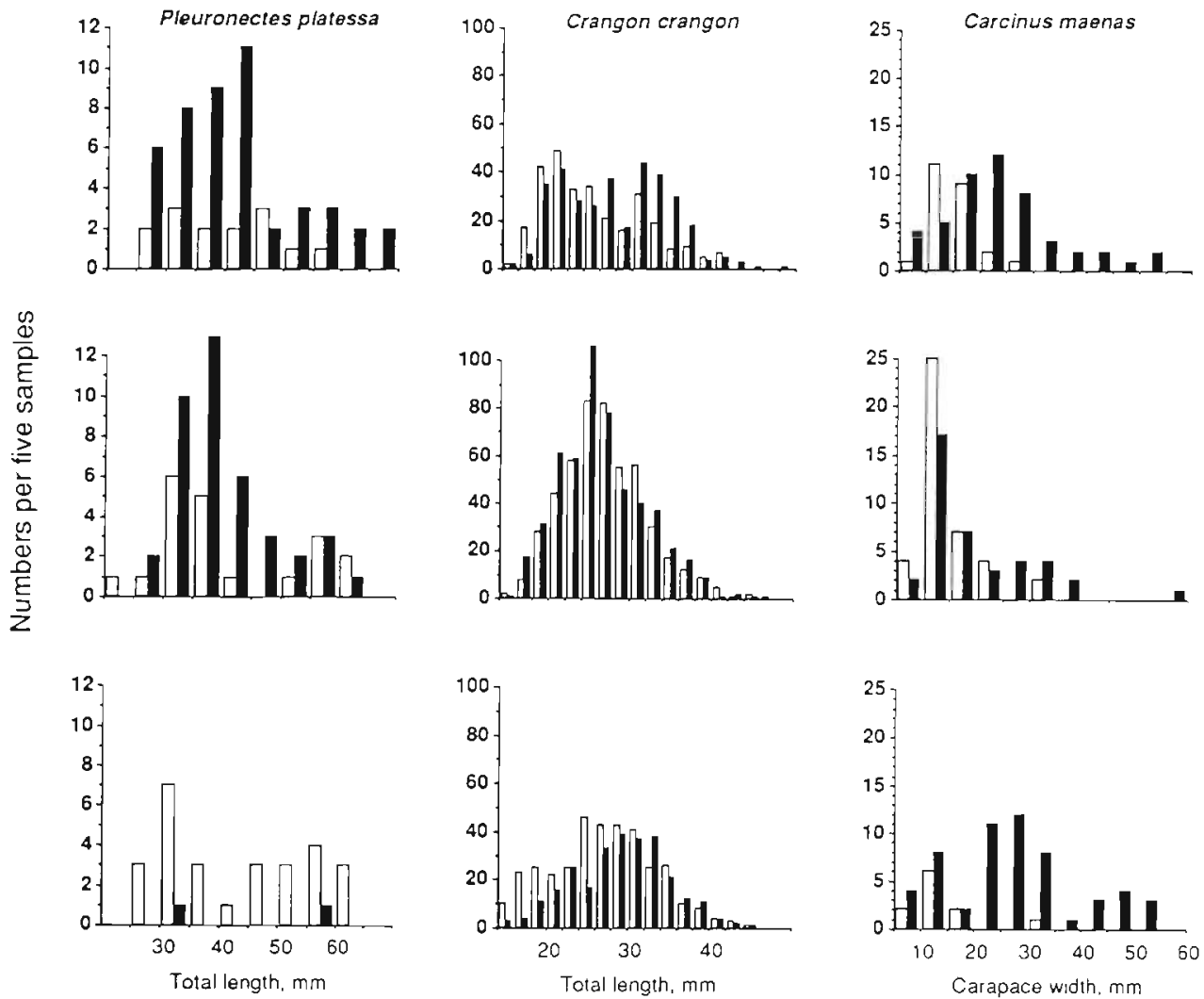

Fig. 8. Size-frequency distributions of Pleuronectes platessa, Crangon crangon and Carcinus maenas caught with the push net at each of the 3 strata during the day (white columns) and the night (black columns). Upper panels, inner stratum; middle panels, middle stratum; lower panels, outer stratum 
Table 3. Two-way Kruskal-Wallis test for effect of factors Area (inner, middle, outer strata) and Time (day, night) on median length. $\mathrm{df}=$ degrees of freedom, $\mathrm{SS}=$ sum of squares. $p<0.05, \cdots p<0.001 ;$ ns: not significant

\begin{tabular}{|c|c|c|c|c|c|c|}
\hline \multirow{2}{*}{$\begin{array}{l}\text { Species: } \\
\text { Data transformation: } \\
\text { Factor }\end{array}$} & \multicolumn{2}{|c|}{$\begin{array}{l}\text { P. platessa } \\
\ln (x+1)\end{array}$} & \multicolumn{2}{|c|}{$\begin{array}{l}\text { C. crangon } \\
\text { None }\end{array}$} & \multicolumn{2}{|c|}{$\begin{array}{l}\text { C. maenas } \\
\text { None }\end{array}$} \\
\hline & SS & $\mathrm{df}$ & SS & $\mathrm{df}$ & SS & $\mathrm{df}$ \\
\hline Time & $22.84 \mathrm{~ns}$ & 1 & $6.53 \mathrm{~ns}$ & 1 & $818.95 \cdots$ & 1 \\
\hline Area & $134.02 \mathrm{~ns}$ & 2 & $1013.60^{\cdots} \cdots$ & 2 & $23.34 \mathrm{~ns}$ & 2 \\
\hline Time $\times$ Area & $657.93 \cdots$ & 2 & $174.07 \mathrm{~ns}$ & 2 & $260.01^{\circ}$ & 2 \\
\hline Residual & 597.85 & 20 & 1052.80 & 24 & 644.35 & 21 \\
\hline
\end{tabular}

where all except one species were represented. Anguilla anguilla and Gadus morhua were the dominant species but only eels occurred frequently in both strata. Myoxocephalus scorpius and Plenronectes platessa were also common in the outer stratum. Individuals from all species ranged in length from 11 to $28 \mathrm{~cm}$, except for eels which reached a total length of $58 \mathrm{~cm}$. Large numbers of smaller fishes $(<10 \mathrm{~cm})$, such as juvenile plaice and flounder, sticklebacks, gobies, sand eels and juvenile herring, were caught in the beach seine both day and night. These fishes were not considered to be potential predators of 0 -group plaice and therefore not analysed further. 0-group plaice were identified in 6 stomachs ( $4 \mathrm{cod}$ and 2 eel) out of the 75 fishes analysed from the beach seine catches. The dominant food was Crangon crangon and Carcinus maenas, together occurring in $56 \%$ of the stomachs. Bivalves were the second most common food item with a frequency of occurrence of $38 \%$. Polychaetes, gobies and amphipods were also found in the stomachs but only in low numbers.

Table 4. Numbers and total length ranges $(\mathrm{cm})$ of larger fishes in beach seine catches during the night in the inner and outer strata

\begin{tabular}{|lrrrc|}
\hline & \multicolumn{2}{c}{ Numbers } & \multicolumn{2}{c|}{$\begin{array}{c}\text { Length range } \\
\text { Snner }\end{array}$} \\
& Inner & Outer & Outer \\
Anguilla anguilla & 15 & 9 & $20-49$ & $12-58$ \\
Gadus morhua & 3 & 14 & $12-24$ & $11-21$ \\
Limanda limanda & 0 & 1 & & 11 \\
Merlangius merlangus & 0 & 1 & & 11 \\
Myoxocephalus scorpius & 0 & 11 & & $11-15$ \\
Platichthys flesus & 3 & 0 & $21-28$ & \\
Pleuronectes platessa & 0 & 8 & & $11-16$ \\
Pollachius virens & 0 & 1 & & 13 \\
Taurulus bubalis & 0 & 4 & & $12-15$ \\
Zoarces viviparus & 1 & 4 & 12 & $17-20$ \\
Total individuals & 22 & 53 & & \\
Total species & 4 & 9 & & \\
\hline
\end{tabular}

\section{Composition of the benthic fauna}

Polychaetes dominated the macrobenthic infauna in all 3 strata, both in terms of number of species and individuals (Table 5), Scoloplos armiger was found in high abundance in almost all samples and was the commonest species. Hediste diversicolor was highly abundant in the inner stratum and species belonging to the family Capitellidae were abundant in the middle and outer strata. Among crustaceans, Corophium volutator was the
Table 5. Mean abundance (individuals per $0.05 \mathrm{~m}^{2}$ ) of benthic infauna retained on a $0.5 \mathrm{~mm}$ sieve in the inner, middle and outer strata in Bökevik Bay on July 4, 1995. Ten core samples were taken randomly in each stratum

\begin{tabular}{|c|c|c|c|}
\hline \multirow[t]{2}{*}{ Taxon } & \multicolumn{3}{|c|}{ Stratum } \\
\hline & Inner & Middaie & outer \\
\hline Nemertines & 3.6 & 0.4 & 1.8 \\
\hline Anthozoa & 0.8 & 0 & 0.5 \\
\hline \multicolumn{4}{|l|}{ Oligochaetes } \\
\hline Tubificoides benedeni & 112.9 & 13.7 & 2.8 \\
\hline \multicolumn{4}{|l|}{ Polychaetes } \\
\hline Capitellidae & 0.9 & 24.5 & 37.3 \\
\hline Hediste diversicolor & 27 & 3.3 & 1.4 \\
\hline Nephtys caeca & 0.1 & 0.4 & 0.5 \\
\hline Scoloplos armiger & 27.2 & 231 & 28.5 \\
\hline Eteone longa & 6.1 & 2.7 & 5 \\
\hline Eulalia sp. & 0 & 0 & 0.1 \\
\hline Spiophanes bombyx & 0.1 & 0.2 & 0.5 \\
\hline Pygospio elegans & 1.2 & 0.6 & 0 \\
\hline Scololepis sp. & 0.1 & 0.5 & 0.3 \\
\hline Spionidae & 0.1 & 0 & 0.1 \\
\hline Magelona mirabilis & 0 & 0 & 0.1 \\
\hline \multicolumn{4}{|l|}{ Amphipods } \\
\hline Gammaropsis sp. & 0 & 0.1 & 0.1 \\
\hline Corophium volutator & 38.6 & 1 & 0 \\
\hline \multicolumn{4}{|l|}{ Molluses } \\
\hline Nassarius reticulata & 0 & 0.1 & 0.3 \\
\hline Mytilus edulis & 0 & 0 & 0.1 \\
\hline Cerastoderma edule & 1 & 1.1 & 7.4 \\
\hline Mya arenaria & 0.6 & 0.6 & 4.9 \\
\hline Abra alba & 3.6 & 0.2 & 0 \\
\hline Tellina tenuis & 2.1 & 1 & 0.6 \\
\hline Mactra sp. & 0.3 & 1.6 & 4.1 \\
\hline Macoma balthica & 0 & 0.4 & 1.6 \\
\hline Mysella bidentata & 0.5 & 0 & 0.2 \\
\hline Chironomidae & 0 & 0.1 & 0 \\
\hline Total polychaetes & 62.8 & 55.3 & 73.8 \\
\hline Total crustaceans & 38.6 & 1.1 & 0.1 \\
\hline Total molluscs & 8.1 & 5.1 & 18.9 \\
\hline Total others & 117.3 & 14.4 & 5.1 \\
\hline
\end{tabular}


only highly abundant species and it was restricted to the inner stratum. Molluscs, mainly represented by Cerastoderma edule and Mya arenaria, occurred in all strata but were found in highest abundances in the outer stratum. The oligochaete, Tubificoides benedeni, was abundant in samples from the inner stratum, but this and other meiofauna species were not considered to have been quantitatively assessed in the fraction retained by a $0.5 \mathrm{~mm}$ sieve.

\section{Dietary analysis of plaice}

The results from the dietary analysis of the 0-group plaice showed that among the macrofaunal crustaceans Corophium volutator and Balanidae (cirri from barnacles) were dominant in the diet in the inner and middle strata, whereas bivalves (Cerastoderma edule, Mya arenaria and Mytilus edulis) were the most common food items in the outer stratum (Table 6). C. volutator was mainly taken by the fish in the inner stratum. Polychaetes contributed little to the diet, but Scoloplos armiger was eaten to some extent in all strata, especially during the night. Meiofauna, especially harpacticoids and ostracods, were abundant in stomachs from fish sampled in the middle and outer strata during the day. When meiofauna were excluded from the analysis, the number of food items taken per fish was similar during day and night, indicating both diurnal and nocturnal feeding activity on larger prey. However, the stomach fullness index was significantly higher $(p=0.001)$ in fish from the night catches (Table 6).

\section{Variation in temperature and water level}

Generally, water level was about $10 \mathrm{~cm}$ above normal during the first half of the study and about $10 \mathrm{~cm}$ below during the second part (Fig. 2). Tidal amplitude varied between 15 and $35 \mathrm{~cm}$ during the investigation. Water temperature at $1 \mathrm{~m}$ depth outside the bay showed a diel variation between 19 and $21^{\circ} \mathrm{C}$ during the sampling period, equivalent to the temper-

Table 6. Diet (number of food items per fish) of 0-group plaice Pleuronectes platessa sampled with a push-net during the day and night in the inner, middle and outer strata. Fishes from the outer stratum at night were supplemented with others from the beach seine because few fish were caught with the push-net

\begin{tabular}{|c|c|c|c|c|c|c|}
\hline \multirow[b]{2}{*}{ Stratum: } & \multicolumn{3}{|c|}{ Day } & \multicolumn{3}{|c|}{ Night } \\
\hline & Inner & Middle & Outer & Inner & Middle & Outer \\
\hline No of stomachs analysed & 15 & 20 & 26 & 47 & 40 & 14 \\
\hline Stomach fullness index & 1.7 & 2.1 & 1.4 & 2.3 & 2.6 & 2.3 \\
\hline Corophium volutator & 7.4 & 0.4 & 0.1 & 3.0 & 0.1 & 1.0 \\
\hline Balanidae & 8.2 & 24.8 & 1.4 & 5.0 & 6.4 & 2.2 \\
\hline Total crustaceans & 15.6 & 25.2 & 1.5 & 8.0 & 6.5 & 3.2 \\
\hline Mya arenaria & 4.2 & 2.4 & 7.8 & 1.9 & 1.8 & 7.2 \\
\hline Cerastoderma edule & 0.7 & 1.9 & 1.3 & 0.3 & 0.3 & 0.7 \\
\hline Mytilus edulis & 0.1 & 1.3 & 6.2 & 0.1 & 0.6 & 1.9 \\
\hline Rissoa membranacea & 0 & 0.3 & 0.3 & 0 & 0.2 & 0 \\
\hline Total molluscs & 5.0 & 5.9 & 15.6 & 2.3 & 2.9 & 9.8 \\
\hline Eteone longa & 0.6 & 0.5 & 0.1 & 0.1 & 0.1 & 0.2 \\
\hline Scoloplos armiger & 0.3 & 0.9 & 0.3 & 2.2 & 3.2 & 2.2 \\
\hline Hediste diversicolor & 0.6 & 0.2 & 0 & 0.5 & 0.3 & 0.2 \\
\hline Spionidae & 0.1 & 0.1 & 0.1 & 0.2 & 0.2 & 0 \\
\hline Polychaeta & 0.2 & 0.5 & 0.5 & 0.5 & 0.4 & 0.4 \\
\hline Capitellidae & 0.6 & 0 & 0 & 0 & 0.8 & 0.4 \\
\hline Total polychaetes & 2.4 & 2.2 & 1.0 & 3.5 & 5.0 & 3.4 \\
\hline Harpacticoida & 0.7 & 8.3 & 64.0 & 1.1 & 11.8 & 2.0 \\
\hline Ostracoda & 0.6 & 18.4 & 6.1 & 0.4 & 1.0 & 4.4 \\
\hline Oligochaeta & 1.2 & 2.2 & 1.7 & 1.4 & 1.2 & 0.5 \\
\hline Foraminifera & 0.5 & 0.2 & 0 & 0.1 & 0 & 0.6 \\
\hline Nematoda & 3.1 & 10.4 & 4.9 & 0.3 & 2.3 & 0.9 \\
\hline Total meiofauna & 6.1 & 39.5 & 76.7 & 2.3 & 16.3 & 8.4 \\
\hline Chironomidae & 0.1 & 0 & 0.1 & 0.1 & 0 & 0.1 \\
\hline Total numbers & 29.2 & 72.8 & 94.9 & 17.2 & 30.7 & 24.9 \\
\hline
\end{tabular}




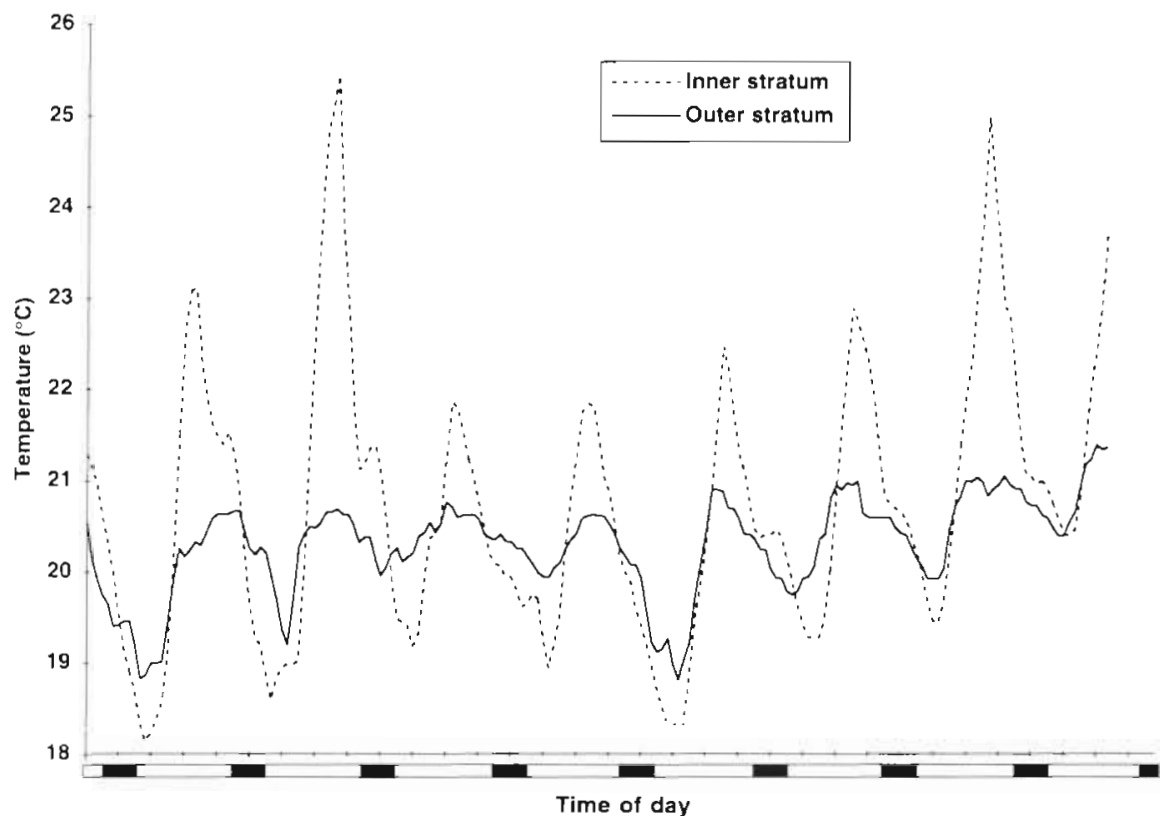

Fig. 9. Diel variations in temperature recorded in the inner stratum (30 $\mathrm{cm}$ depth) and in the outer stratum (120 cm depth) the week after sampling was performed in Bökevik. Bars at the bottom of the graph indicate periods of light and dark ature range recorded during 8 diel cycles in early August at $1 \mathrm{~m}$ depth in the outer stratum of the bay (Fig. 9). In the inner stratum (30 cm depth), however, diel variations in temperature were considerably higher and ranged from 18 to $26^{\circ} \mathrm{C}$. Measurements along transects from the shore to $130 \mathrm{~m}$ out towards the mouth of the bay showed a decrease in mean temperature at $14: 00 \mathrm{~h}$ from 25.2 to $19.8^{\circ} \mathrm{C}$. At night (02:00 h), the gradient was reversed and water temperature increased along the same transect from 19.0 to $20.5^{\circ} \mathrm{C}$ (Fig. 10 ).

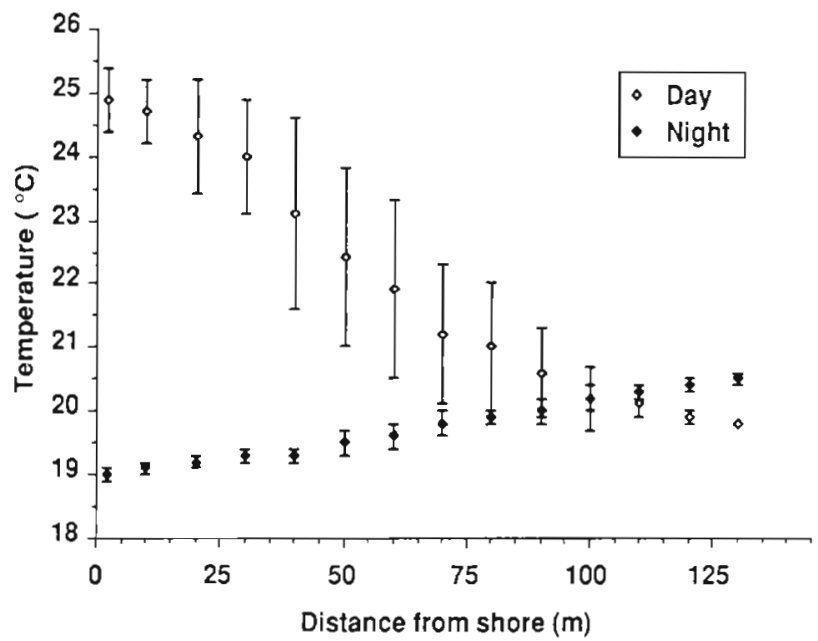

Fig. 10. Temperature profiles (means of 4 transects \pm SD) recorded at the study site during the day and night

\section{DISCUSSION}

The overall picture that emerges from this study is one of a complex series of spatial and temporal changes in distribution of the larger members of the community. In summary, larger predatory fishes entered the shallow waters of the bay at night and fed on smaller fishes (plaice and gobies) and dominant macrocrustaceans (shrimps and crabs). The levels of activity and distribution of these prey organisms also changed over the diel cycle. Small plaice moved into shallower water at night followed by a return to deeper water at dawn. The same tendency was shown by gobies. The distribution of crabs and shrimps, in contrast, changed little over $24 \mathrm{~h}$, although crabs were markedly nocturnal and shrimps strongly diurnal in their activity. These patterns of distribution and activity were inferred from the results of 2 different sampling techniques, those of underwater television observation and standard sampling methods. The results from the 2 approaches were generally similar and each provided confirmation of the major trends observed. For example, the upshore/downshore migrations of the larger predatory fishes were recorded by the television camera and confirmed by beach seine catches. Similarly, the movements of plaice seen by the camera were reflected in the greater catches with a push net in shallower water at night and in deeper water during the day. Further comparison of the results of sampling with the TV camera and the nets provided insight into the behaviour of shrimps and crabs. The net samples showed that there were no overall changes in abundance of shrimps in any of the depth strata over $24 \mathrm{~h}$ 
and the camera observations indicated there were no major changes in distribution between day and night. The camera results also demonstrated the presence of a strong diurnal rhythm of activity in shrimps, possibly representing the manifestation of a rhythm of undirected feeding activity in this species. In a previous study in the area in midsummer, peaks of feeding activity were recorded during the day with periods of lower activity at night when the shrimps bury themselves in the sand (Pihl \& Rosenberg 1984). A clear dawn and dusk feeding pattern has been recorded in spring and autumn with a tendency for night activity to increase when days shorten (Pihl \& Rosenberg 1984). In midsummer when nights are short, activity rhythms are less pronounced but feeding peaks occur during the day. The behaviour of crabs seemed to be the opposite of that shown by shrimps. The TV camera recorded many more at night, as did the net samples in the inner and outer strata. This increase in numbers was caused mainly by the appearance of larger individuals. The apparent lack of any migratory movements within the bay by crabs suggests that these larger individuals may remain buried in the sediment during the day and only emerge at night. One curious finding is that this phenomenon did not seem to occur in the middle stratum, possibly because this area has a coarser sediment which might prevent the crabs burying themselves efficiently.

The patterns of movement and activity observed during this study are comparable to those recorded elsewhere. Gadoids move into shallow water at night in many areas (Pihl 1982, Keats 1990, Gibson et al. 1996), as do young plaice (Bregneballe 1961, Burrows et al. 1994). Carcinus maenas, although it can be active at all times of day (Hunter \& Naylor 1993), is mainly nocturnal in most areas (Burrows et al. 1994, Aagaard et al. 1995). The activity patterns of Crangon crangon seem to vary widely between locations and seasonally. It may be active during the day (this study), at night (Hagerman 1970, Al-Adhub \& Naylor 1975, Burrows et al. 1994) or at dusk and dawn (Pihl \& Rosenberg 1984, del Norte-Campos \& Temming 1994). In locations where the tidal range is large, the movements of plaice (Gibson 1973, Kuipers 1973, Burrows et al. 1994), crabs (Dare \& Edwards 1981, Hunter \& Naylor 1993) and shrimp (Al-Adhub \& Naylor 1975) may have an additional tidal component, although in C. maenas this component has also been detected where tides are weak (Aagaard et al. 1995 and this paper). Conversely, in the Wadden Sea, which has a large tidal range, only a very small proportion of the shrimp population undertakes a tidal migration (Janssen \& Kuipers 1980).

Three main functions have been ascribed to these movements, namely foraging, predator avoidance and the selection of suitable environmental conditions.
None of these functions is mutually exclusive and the patterns of movement observed are likely to represent a compromise or trade-off between all three (Burrows 1994). During early ontogeny, habitat shifts are common in marine fish species (van der Veer \& Bergman 1986, Boehlert \& Mundy 1988, Jones 1990), and habitat use by juveniles is often controlled by a foraging rate predation risk trade-off mechanism (Werner \& Hall 1988, Burrows 1994). The nursery habitat provides an environment that reduces predation mortality and optimizes feeding and growth. Small scale movements related to foraging and predator avoidance within a nursery could further enhance the survival and growth of juvenile fishes. In the present case, the upshore movement of plaice precedes that of their potential fish predators and the downshore movement does not occur until the majority of predators have departed. Such a movement could therefore be interpreted as a shift in distribution that minimises the risk of predation by fishes. At the time when the observations were made most plaice were too large (>30 mm) to make them vulnerable to predation by shrimps and crabs (van der Veer \& Bergman 1987, Gibson et al. 1995). Considering these crustaceans as prey and competitors rather than as predators, the TV observations that shrimps are predominantly day-active and may bury themselves in the sand during the night suggest that such a stategy would reduce the predation on them by the nocturnally immigrating larger fishes. This risk is not eliminated, however, because analysis of the stomach contents of these larger fishes showed that shrimps featured in the diet of 8 species. In comparison, crabs were more active at night although the nocturnally active individuals were larger and presumably less vulnerable to predation. Crabs were, however, found in the stomachs of 4 species of predator and were present in $45 \%$ of the Myoxocephalus scorpius examined.

No clear difference in overall abundance of suitable food for plaice was detected between the inner and outer strata and they seemed to feed on the most abundant item at their current location. However, food consumption was significantly higher at night, indicating an active search for food, and Corophium volutator, which was only present in the inner stratum, was dominant in their diet at this time. This nocturnal feeding in shallow water is likely to result in decreased competition with the diurnally active shrimp population. In comparison, the diets of plaice and gobies show little overlap (Macer 1967, Evans 1983) and their movement patterns are apparently similar (Fig. 5d, g).

In terms of a response to physical factors, the return of plaice to deeper water in the morning resulted in the avoidance of high temperatures $\left(25\right.$ to $\left.26^{\circ} \mathrm{C}\right)$ in shallow water during the day. Zahn (1963) demonstrated that fish of 15 to $23 \mathrm{~cm}$ exhibit a preference for approxi- 
mately 18 to $20^{\circ} \mathrm{C}$ in the laboratory and that this preference depends on the adaptation temperature and changes seasonally. Furthermore, Fonds et al. (1992) showed that both growth and food consumption of fish 4 to $8 \mathrm{~cm}$ decrease in temperatures above $20^{\circ} \mathrm{C}$. The upshore/downshore movement could therefore also be seen as a strategy that keeps the fish as close to their preferred temperature as possible.

The tidal amplitude is small in the investigated area (mean variation in water level about $20 \mathrm{~cm}$ ) and activity patterns and up-and downshore movements could not be related to the tidal cycle for any of the species studied. In areas with larger tidal ranges, the fauna often follows the tide, thereby utilizing the upshore areas for feeding and as a refuge from predation during high tide (Gibson 1973, van der Veer \& Bergman 1986, Ansell \& Gibson 1990). In a microtidal area, as in the present study, even though the distribution of prey species may vary within the bay, food resources are always available because the sediment is more or less permanently covered with water. Consequently there is less need for animals to undertake feeding migrations in areas with a small tidal range compared with areas where the tidal influence is large. However, the value of the shallowest areas as a refuge from predation could be equally important in both areas.

The environmental cues the various species use to time their movements are also unknown but examination of the movement patterns in relation to both biotic and abiotic factors suggests that the timing of immigration and emigration is mainly made in relation to abiotic factors, and particularly to changes in light intensity. Tidally induced changes in water level seem to be of little importance in regulating the observed movements. If this is so, then each species responds to changing light intensity in a different way. Crangon crangon activity, as measured by their frequency of appearance under the camera, closely follows the course of changing light intensity over the day (Fig. 3d) whereas the activity of Carcinus maenas builds up gradually during the night and ceases abruptly after sunrise (Fig. 3a). Plaice (Fig. 3b) are most active at sunset and sunrise and this pattern, coupled with a strong directional movement, results in their marked upshore/downshore movement. In contrast, several of the fish predators diffuse gradually into shallower water once it is dark and leave rapidly as light intensity increases at or before surrise. Overall, it is likely that the behaviour patterns observed are a mixture of responses to the physical environment modified by direct interactions with other organisms, be they competitors, predators or prey. Such responses will have been selected over evolutionary time to produce maximum survival and growth for all species concerned.
Acknowledgements. R.N.G., M.T.B. and L.A.N, thank the Director for permission to use the excellent facilities at the Kristineberg Marine Research Station during their stay. The authors also gratefully acknowledge the help of Donja MacGregor and Linda Robb in the analysis of the videotapes and Malin Werner and Sven Nilsson for the analyses of the stomach contents.

\section{LITERATURE CITED}

Aagaard A, Warman CG, Depledge MH (1995) Tidal and seasonal changes in the temporal and spatial distribution of foraging Carcinus maenas in the weakly tidal littoral zone of Kerteminde Fjord, Denmark. Mar Ecol Prog Ser 122: $165-172$

A.-Adhub AHY, Naylor E (1975) Emergence rhythms and tidal migrations of the brown shrimp Crangon crangon (L.). J Mar Biol Assoc UK 55:801-810

Ansell AD, Gibson RN (1990) Patterns of feecing and movement of juvenile flatfishes on an open sandy beach. In: Barnes $M_{1}$ Gibson RN (eds) Trophic relationships in the marine environment. Aberdeen University Press, Aberdeen, p 191-207

Boehlert GW, Mundy BC (1988) Roles of behavioral and physical factors in larval and juvenile fish recruitment to estuarine nursery areas. Am Fish Soc Sumn 3:51-67

Bregneballe F (1961) Plaice and flounder as consumers of the microscopic bottom fauna. Medd Danm Fisk Havunders 3:133-182

Brown AC, McLachlan A (1991) Ecology of sandy shores Elsevier, Amsterdam

Burrows MT (1.994) An optimal foraging and migration model for juvenile plaice. Evol Ecol 8:125-149

Burrows MT, Gibson RN, Robb L, Comely CA (1994) Temporal patterns of movement in juvenile flatfishes and their predators: underwater television observations. J Exp Mar Biol Ecol 177:251-268

Dare PJ, Edwards DB (1981) Underwater television observations on the intertidal movements of shore crabs, Carcinus maenas, across a mudflat. J Mar Biol Assoc UK 61:107-116

del Norte-Campos AGC, Temming A (1994) Daily activity, feeding and rations in gobies and brown shrimp in the northern Wadden Sea. Mar Ecol Prog Ser 115:41-53

Edwards RL (1958) Movements of individual members in a population of the shore crab, Carcinus maenas, in the littoral zone. J Anim Ecol 27:37-46

Evans S (1983) Production, predation and food niche segregation in. a marine shallow soft-bottom community. Mar Ecol Prog Ser 10:147-157

Fonds M, Cronie R, Vethaak AD, van der Puyl P (1992) Metabolism, food consumption and growth of plaice (Pleuronectes platessa) and flounder (Platichthys flesus) in relation to fish size and temperature. Neth J Sea Res 29: $127-143$

Gibson RN (1973) The intertidal movements and distribution of young fish on a sandy beach with special reference to the plaice (Pleuronectes platessa L). J Exp Mar Biol Ecol 12:79-102

Gibson RN (1980) A quantatitive description of the behaviour of wild juvenile plaice (Pleuronectes platessa L.). Anim Behav 28:1202-1216

Gibson RN, Ansell AD, Robb L (1993) Seasonal and annual variations in abundance and species composition of fish and macrocrustacean communities on a Scottish sandy beach. Mar Ecol Prog Ser 98:89-105

Gibson RN, Hesthagen IH (1981) A comparison of the activ- 
ity patterns of the sand goby Pomatoschistus minutus (Pallas) from areas of different tidal range. J Fish Biol 18: $669-684$

Gibson RN, Robb L (1996) Piscine predation on juvenile fishes on a Scottish sandy beach. J Fish Biol 49:120-138

Gibson RN, Robb L, Burrows MT, Ansell AD (1996) Tidal, diel and longer term changes in the distribution of fishes on a Scottish sandy beach. Mar Ecol Prog Ser 130:1-17

Gibson RN, Yin MC, Robb L (1995) The behavioural basis of the predator-prey size relationships between shrimp (Crangon crangon) and juvenile plaice (Pleuronectes platessa). J Mar Biol Assoc UK 57:337-349

Hagerman L (1970) Locomotory activity patterns of Crangon vulgaris (Fabricius) (Crustacea, Natantia). Ophelia 8: $255-266$

Healey MC (1971) The distribution and abundance of sand gobies, Gobius minutus in the Ythan estuary. J Zool Lond 163:177-229

Hunter E, Naylor E (1993) Intertidal migration by the shore crab Carcinus maenas. Mar Ecol Prog Ser 101:131-138

Janssen GM, Kuipers BR (1980) On tidal migration in the shrimp Crangon crangon. Neth J Sea Res 14:339-348

Jones GP (1990) The importance of recruitment to the dynamics of a coral reef fish population. Ecology 71:1991-1998

Keats DW (1990) A nocturnal inshore movement of juvenile cod Gadus morhua L. in eastern Newfoundland. J Exp Mar Biol Ecol 139:167-173

Kuipers BR (1973) On the tidal migration of young plaice (Pleuronectes platessa) in the Wadden Sea. Neth $J$ Sea Res $6: 376-388$

Macer CT (1967) The food web in Red Wharf Bay (North Wales) with particular reference to young plaice (Pleuronectes platessa). Helgoländer Wiss Meeresunters 15: 560-573

Modin J, Pinl L (1994) Differences in growth and mortality of juvenile plaice, Pleuronectes platessa L., following normal

Editorial responsibility: Otto Kinne (Editor),

Oldendorf/Luhe, Germany and extremely high settlement. Neth J Sea Res 32:331-34 1

Pihl L (1982) Food intake of young cod and flounder in a shallow bay on the Swedish west coast. Neth J Sea Res 15: $419-432$

Pihl L (1985) Food selection and consumption of mobile epibenthic fauna in shallow marine areas. Mar Ecol Prog Ser 22:169-179

Pihl L (1986) Exposure, vegetation and sediment as primary factors for mobile epibenthic faunal community structure and production in shallow marine soft bottom areas. Neth J Sea Res 20:75-83

Pihl L, Rosenberg R (1982) Production, abundance and biomass of mobile epibenthic marine fauna in shallow waters, western Sweden. J Exp Mar Biol Ecol 57:273-301

Pihl L, Rosenberg R (1984) Food selection and consumption of the shrimp Crangon crangon in some shallow marine areas in western Sweden. Mar Ecol Prog Ser 15:159-168

SAS Institute Inc. (1990) SAS procedures guide. Version 6, 3rd edn. SAS Institute Inc, Cary, NC

van der Veer HW, Bergman MJN (1986) Development of tidally related behaviour of a newly settled 0-group plaice (Pleuronectes platessa) population in the western Wadden Sea. Mar Ecol Prog Ser 31:121-129

van der Veer HW, Bergman MJN (1987) Predation by crustaceans on a newly settled 0 -group plaice Pleuronectes platessa population in the western Wadden Sea. Mar Ecol Prog Ser 35:203-215

Werner EE, Hall DJ (1988) Ontogenetic habitat shifts in bluegill: the foraging rate-predation risk trade-off. Ecology 69:1352-1366

Zahn M (1963) Jahreszeitliche Veränderungen der Vorzugstemperaturen von Scholle (Pleuronectes platessa Linne) und Bitterling (Rhodeus sericeus Pallas). Verh Dt Zool Ges $27: 562-580$

Zar JH (1995) Biostatistical analysis. Prentice Hall, Upper Saddle River, NJ

Submitted: August 7, 1997; Accepted: February 11, 1998 Proofs received from author(s): April 9, 1998 